\title{
Pengaruh Kualitas Pelayanan Dan Promosi Terhadap Kepuasan Pelanggan OVO (Studi Kasus Pada Mahasiswa STIE Eka Prasetya)
}

\author{
${ }^{1}$ Sri Rezeki \\ ${ }^{2}$ Desma Erica Maryati M. \\ ${ }^{3}$ Muammar Rinaldi* \\ STIE Eka Prasetya, Indonesia \\ muammar@eka-prasetya.ac.id
}

\begin{abstract}
The purpose of this study is to determine the effect of Service Quality and Promotion on OVO Customer Satisfaction. The research methodology used is quantitative descriptive method, the unit of analysis in this study is STIE Eka Prasetya and the observation unit is students from STIE Eka Prasetya. The population in this study were 993 respondents from STIE Eka Prasetya. The technique of determining the number of samples used in this study is the Slovin formula and amounted to 91 respondents. The research method used is the technique of data collection through the distribution of questionnaires that conducted systematically based on research objectives. The analytical method used to solve problems and prove hypotheses is descriptive analysis and regression analysis. This analysis includes validity and reliability, classic assumption tests, multiple linear regression analysis, hypothesis testing through $\mathrm{t}$ and $\mathrm{F}$ tests, and the coefficient of determination $\left(\mathrm{R}^{2}\right)$ test. The results of the $t$ test show that the variable Service Quality has a positive and significant effect on OVO Customer Satisfaction, and the Promotion variable has a positive and significant effect on OVO Customer Satisfaction. The results of the F test show that the Service Quality and Promotion simultaneously effect the Customer Satisfaction. The result of coefficient of determination test results $\left(\mathrm{R}^{2}\right)$ shows that Customer Satisfaction was effected by Service Quality and Promotion variables, while the remaining is explained by other variables such as perception, digital marketing and personal selling that are not discussed in this study.
\end{abstract}

Keywords: Service Quality; Promotion; Customer Satisfaction

\begin{abstract}
ABSTRAK
Tujuan dari penelitian ini adalah untuk mengetahui pengaruh Kualitas Layanan dan Promosi terhadap Kepuasan Pelanggan OVO. Metodologi penelitian yang digunakan adalah metode deskriptif kuantitatif, unit analisis dalam penelitian ini adalah STIE Eka Prasetya dan unit observasi adalah mahasiswa STIE Eka Prasetya. Populasi dalam penelitian ini adalah 993 responden dari STIE Eka Prasetya. Teknik penentuan jumlah sampel yang digunakan dalam penelitian ini adalah rumus Slovin dan berjumlah 91 responden. Metode penelitian yang digunakan adalah teknik pengumpulan data melalui penyebaran kuesioner yang dilakukan secara sistematis sesuai dengan tujuan penelitian. Metode analisis yang digunakan untuk memecahkan masalah dan membuktikan hipotesis adalah analisis deskriptif dan analisis regresi. Analisis ini meliputi uji validitas dan reliabilitas, uji asumsi klasik, analisis regresi linier berganda, uji hipotesis melalui uji t dan uji F, dan uji koefisien determinasi (R2). Hasil uji t menunjukkan bahwa variabel Kualitas Layanan berpengaruh positif dan signifikan terhadap Kepuasan Pelanggan OVO, dan variabel Promosi berpengaruh positif dan signifikan terhadap Kepuasan Pelanggan OVO. Hasil uji F menunjukkan bahwa Kualitas Pelayanan dan Promosi berpengaruh secara simultan terhadap Kepuasan Konsumen. Hasil uji koefisien determinasi (R2) menunjukkan bahwa Kepuasan Pelanggan dipengaruhi oleh variabel Kualitas Pelayanan dan Promosi, sedangkan sisanya dijelaskan oleh variabel lain seperti persepsi, digital marketing dan personal selling yang tidak dibahas dalam penelitian ini.
\end{abstract}


Kata Kunci: Kualitas Pelayanan; Promosi; Kepuasan pelanggan

\section{PENDAHULUAN}

Perkembangan teknologi yang semakin pesat terutama pada bagian penyedia layanan finansial yang dulunya pembayaran masih berupa uang tunai sekarang perlahan-lahan mengarah ke arah digital (cashless). Tanpa kita sadari segala hambatan dalam transaksi konvensional dapat teratasi berkat era digital yang semakin maju, dimana peredaran uang tunai tidak sebanyak dulu lagi. Adanya perangkat seluler dan perkembangan teknologi nirkabel di tengah kehidupan masyarakat menyebabkan mobile payment berkembang pesat.

Uang yang dibayarkan melalui mobile payment adalah uang elektronik (e-money). Uang elektronik adalah instrumen pembayaran non-tunai. Uang elektronik menyimpan sejumlah uang yang memiliki kapasitas maksimal saldo sesuai dengan nilai yang ditentukan dari vendor tersebut. Awalnya uang elektronik diterbitkan oleh sejumlah bank dalam bentuk kartu, namun seiring berkembangnya zaman kini muncul uang elektronik berbasis aplikasi yang lebih memudahkan penggunanya tanpa harus mengeluarkan kartu atau mengambil kartu kemanamana. Karena cenderung zaman sekarang masyarakat luas sudah memiliki ponsel pintar.

Salah satu aplikasi yang menyediakan layanan pembayaran non-tunai yaitu OVO. Aplikasi ini merupakan produk uang elektronik yang diluncurkan oleh PT Visionet Internasional. OVO sendiri sudah mendapatkan izin dari Bank Indonesia (BI) sebagai penyelenggara uang elektronik sejak Agustus 2016. OVO merupakan aplikasi yang dapat kita gunakan untuk melakukan transaksi pembelian, pembayaran jasa, makanan dan minuman, hiburan, dan pengiriman uang pada bank umumnya serta OVO merupakan salah satu produk keuangan yang sangat diminati oleh berbagai kalangan.

Di Indonesia, OVO berkembang dengan pesat dengan memperkuat platform-nya dengan mengembangkan QR Code untuk mendukung pemberdayaan UMKM (Usaha Mikro, Kecil, Menengah). Fungsi QR Code ini adalah untuk membantu pedagang menyediakan moda pembayaran agar customer tidak perlu membawa uang fisik dan mengefesiensikan jalannya pembayaran. OVO mengembangkan bisnisnya hampir seluruh Indonesia khususnya di Sumatera Utara. Di Sumatera Utara sendiri OVO banyak bekerjasama dengan merchantmerchant yang hanya ada di kota medan contohnya XO Suki yaitu bisnis restoran yang memakai jasa OVO sebagai moda pembayarannya dan Sky Parking yang lokasinya di Sun Plaza Medan sebagai penyedia tempat parkir yang sistem pembayarannya hanya menerima pembayaran dengan menggunakan OVO. Hal tersebut secara tidak langsung mengharuskan pengunjung ataupun customer yang datang wajib memiliki aplikasi OVO untuk melakukan transaksi tersebut.

Selain OVO ada bebagai macam penyedia layanan uang elektronik yaitu Go-Pay milik aplikasi transportasi online Go-Jek, DANA hasil joint venture PT Elang Mahkota Teknologi Tbk dan Ant Financial (Alipay) dan sebagainya. Munculnya OVO sebagai penyelenggaran uang elektronik terbilang cukup terlambat dibanding dengan kompetitornya yang lain tetapi hal ini tidak membuat OVO tidak diminati pada bebagai kalangan. OVO berkembang pesat sejak awal dirilisnya aplikasi ini. 
Setelah banyak diluncurkannya aplikasi penyedia layanan uang elektronik, pasti ada alasannya mengapa OVO dapat bersaing dengan penyedia layanan uang elektronik lainnya. Menurut penulis salah satu penyebabnya adalah kepuasan pelanggan. Tjiptono (2019) menyatakan bahwa kepuasan pelanggan adalah perasaan senang atau kecewa yang didapatkan seseorang dari membandingkan antara kinerja (atau hasil) produk yang dipersepsikan dan ekspetasinya. Faktor-faktor yang menyebabkan pelanggan OVO tetap setia menggunakan OVO sebagai penyedia layanan uang elektronik mereka adalah kualitas pelayanan yang diberikan OVO yang baik,cepat dan mudah serta Promosi yang diberikan dengan berbagai macam platform sehingga dapat memudahkan pelanggan untuk mendapatkan informasi terbaru mengenai promo ataupun kebijakan terbaru.

Kualitas pelayanan mencerminkan perbandingan antara tingkat pelayanan yang disampaikan perusahaan dibandingkan ekspetasi pelanggan (Tjiptono, 2008). Kualitas pelayanan yang diberikan OVO semakin lama semakin baik karena OVO menciptakan fiturfitur ataupun tampilan yang semakin hari semakin efisien dalam penggunaannya hal tersebut dilakukan untuk meningkatkan kepuasan pelanggan dalam pemakaian OVO. OVO menyediakan website www.ovo.co.id untuk memberikan pelanggan berbagai informasi yang dibutuhkan. Terdapat 2 jenis pelayanan yang disediakan yaitu call center yang memiliki jam operasional 24 jam berfungsi untuk menanggapi keluhan customer secara online sehingga pengguna tidak perlu mengalami kerepotan jika tidak dapat ke gerai offline. Jenis pelayanan lain yang disediakan OVO adalah pelayanan bersifat offline. Pengguna yang kurang paham dengan sistematika online dapat terbantu dengan pelayanan yang diberikan langsung dengan mengunjungi gerai OVO atau biasa disebut dengan OVO Booth. Sehingga pelayanan OVO terbilang cukup lengkap dengan adanya sistem online dan gerai OVO Booth.

Dalam manajemen pemasaran dikatakan bahwa promosi merupakan ujung tombak kegiatan bisnis suatu produk dalam rangka menjangkau pasar sasaran dan menjual produk tersebut (Sunyoto, 2015). Promosi memiliki daya tarik dan menjadi salah satu faktor dalam membangun kepuasan pelanggan. Media promosi yang digunakan OVO sangat bermacammacam jenisnya yaitu dengan menggunakan banner, spanduk, dan sebagainya. Di sisi lain selain memberikan promosi dengan cara pada umumnya, OVO juga bekerjasama dengan GRAB (transportasi online) dalam mempromosikan produk penyedia layanan uang elektronik. Kegiatan promosi yang dilakukan oleh OVO antara lain Advertising, Personal Selling dan Sales Promotion.

Dampak penggunaan OVO juga dirasakan oleh kaum pelajar, terutama pada mahasiswa. Dengan adanya OVO mahasiswa lebih dimudahkan dalam melakukan transaksi, salah satu contohnya seperti pembayaran transportasi online (Grab). Penulis sendiri akan melakukan penelitian terhadap mahasiswa di salah satu kampus di kota Medan yaitu STIE Eka Prasetya.

\section{KAJIAN LITERATUR}

\subsection{Kepuasan Pelanggan}

Menurut Tjiptono dan Diana (2019), “Kepuasan Pelanggan adalah perasaan senang atau kecewa yang didapatkan seseorang dari membandingkan antara kinerja (atau hasil) produk yang 
dipersepsikan dan ekspektasinya." Tjiptono dan Diana (2019) menyebutkan bahwa terdapat 5 konsep untuk mengukur Kepuasan Pelanggan yaitu sebagai berikut :

1. Kepuasan Pelanggan Keseluruhan (Overall Customer Satisfaction)

2. Konfirmasi Ekspektasi (Confirmation of Expectations)

3. Nilai Beli Ulang (Repurchase Intent)

4. Kesediaan Untuk Merekomendasi (Willingness to Recommend)

5. Ketidakpuasan Pelanggan (Customer Dissatisfaction)

\subsection{Kualitas Pelayanan}

Menurut Tjiptono dan Chandra (2012), "Kualitas Layanan adalah mencerminkan perbandingan antara tingkat layanan yang disampaikan perusahaan dibandingkan ekspektasi pelanggan." Menurut Tjiptono dan Chandra (2012) dalam kasus pemasaran dimensi Kualitas Pelayanan yang paling sering menjadi acuan yaitu sebagai berikut : 1) Reliabilitas, 2) Responsivitas, 3) Jaminan, 4) Empati, 5) Bukti fisik.

\subsection{Kualitas Pelayanan}

Menurut Hasan (2013), "Promosi merupakan proses mengkomunikasikan variabel pemasaran (marketing mix) yang sangat penting untuk dilaksanakan perusahaan dalam memasarkan produk." Menurut Hasan (2013), terdapat beberapa indikator promosi yaitu sebagai berikut : 1) Periklanan, 2) Pemasaran langsung, 3) Penjualan tatap muka, 4) Promosi penjualan.

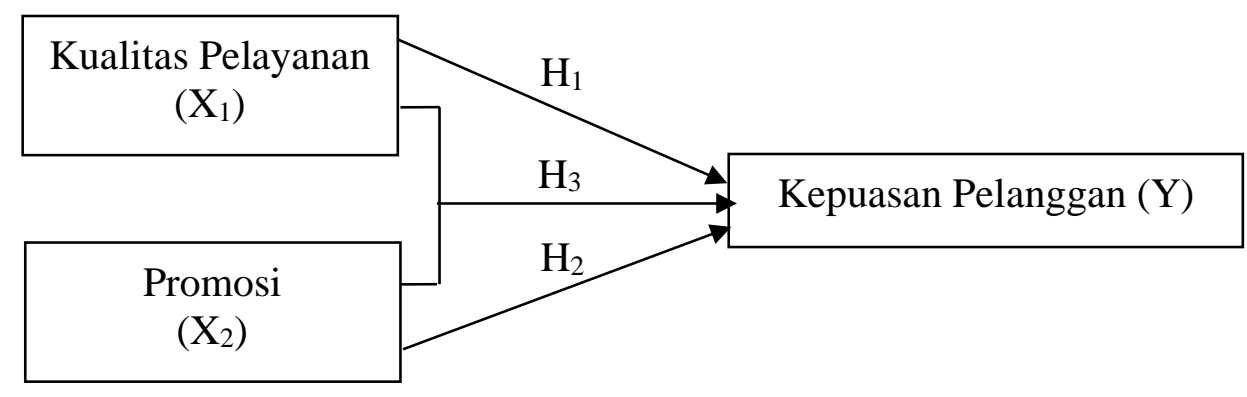

Gambar 1. Kerangka Penelitian

\section{METODE PENELITIAN}

\section{Lokasi Penelitian}

Penelitian ini dilakukan pada STIE Eka Prasetya Medan yang beralamat di Jl. Merapi No.8, Pusat Ps., Kec. Medan Kota, Kota Medan, Sumatera Utara 20212.

\section{Populasi dan Sampel}

Populasi dalam penelitian ini adalah mahasiswa STIE Eka Prasetya angkatan 2016 sebanyak 218 orang, angkatan 2017 sebanyak 243 orang, angkatan 2018 sebanyak 223 orang, dan angkatan 2019 sebanyak 309 orang di Tahun Ajaran 2019/2020 dengan total 993 orang.

Teknik pengambilan sampel penelitian ini menggunakan rumus Slovin. Sehingga sampel penelitian ini sebanyak 91 responden. 


\section{Teknik Pengumpulan Data}

Metode pengumpulan data yang digunakan dalam penelitian ini adalah metode angket (kuesioner terstruktur) yang diberikan kepada responden. Metode angket menurut Sugiyono (2016:142) merupakan teknik pengumpulan data yang dilakukan dengan cara memberi seperangkat pertanyaan atau pernyataan tertulis kepada responden untuk menjawabnya.

\section{Teknik Analisis Data}

Dalam penelitian ini, teknik analisis regresi linier berganda digunakan. Analisis regresi linear berkaitan dengan studi mengenai ketergantungan variabel dependen (terikat) dengan variabel independen (bebas), dengan tujuan untuk mengestimasi dan memprediksi rata-rata populasi atau nilai rata-rata variabel dependen berdasarkan nilai independen yang diketahui. Analisis linear berganda digunakan untuk mengetahui pengaruh Kualitas Pelayanan $\left(\mathrm{X}_{1}\right)$ dan Promosi $\left(\mathrm{X}_{2}\right)$ terhadap Kepuasan Pelanggan $(\mathrm{Y})$. Perhitungan dapat dirumuskan dengan formula sebagai berikut:

$$
\mathrm{Y}=\alpha+\beta 1 \mathrm{X} 1+\beta 2 \mathrm{X} 2+\beta 3 \mathrm{X3}+\mathrm{e}
$$

Keterangan:

$\mathrm{Y} \quad=\quad$ Kepuasan Konsumen (Dependent Variable)

$\mathrm{X} 1=$ Kualitas Pelayanan (Independent Variable)

$\mathrm{X} 2=$ Promosi (Independent Variable)

$\mathrm{X} 3=$ Lokasi (Independent Variable)

$\alpha=$ Konstanta

$\beta 1=$ Koefisien untuk variabel Kualitas Pelayanan

$\beta 2=$ Koefisien untuk variabel Promosi

$\beta 3=$ Koefisien untuk variabel Lokasi

e $\quad=\quad$ Standard Error $(5 \%)$

\section{HASIL DAN PEMBAHASAN}

\section{Karakteristik Responden}

Karakteristik responden berdasarkan jenis kelamin yaitu responden laki-laki berjumlah 28 orang $(30,8 \%)$ dan responden perempuan berjumlah 63 orang $(69,2 \%)$. Hal ini dapat disimpulkan bahwa secara keseluruhan responden perempuan karena memiliki persentase yang lebih tinggi.

Karakteristik responden berdasarkan usia yaitu responden berusia $<21$ tahun berjumlah 61 orang $(67 \%)$, responden berusia $21-25$ tahun berjumlah 29 orang (31,9\%), dan responden berusia $>25$ tahun berjumlah 1 orang $(1,1 \%)$. Hal ini menjelaskan bahwa secara keseluruhan usia responden adalah $<21$ tahun karena memiliki persentase yang lebih tinggi.

\section{Uji Validitas dan Uji Reliabilitas}

Menurut Ghozali (2016), mengukur validitas dan reliabilitas dapat dilakukan dengan cara melakukan korelasi antar skor butir pertanyaan dengan total skor konstruk atau variabel.

Hasil uji Validitas dan Reliabilitas akan disajikan pada tabel 1 dan tabel 2. 
Tabel 1. Hasil Uji Validitas

\begin{tabular}{|c|c|c|c|}
\hline No & Pernyataan & Variabel & $\mathrm{r}_{\text {hitung }}$ \\
\hline 1 & KP-1 & & 0,572 \\
\hline 2 & KP-2 & Kualitas Pelayanan & 0,800 \\
\hline 3 & KP-3 & & 0,890 \\
\hline 4 & KP-4 & & 0,601 \\
\hline 5 & KP-5 & & 0,691 \\
\hline 1 & P-1 & & 0,415 \\
\hline 2 & P-2 & Promosi & 0,789 \\
\hline 3 & P-3 & & 0,861 \\
\hline 4 & P-4 & & 0,900 \\
\hline 1 & KP-1 & & 0,683 \\
\hline 2 & KP-2 & Kepuasan Pelanggan & 0,793 \\
\hline 3 & KP-3 & & 0,783 \\
\hline 4 & KP-4 & & 0,818 \\
\hline 5 & KP-5 & & 0,645 \\
\hline
\end{tabular}

Sumber : Hasil Olah Data, 2020

Dari tabel 1 diperoleh nilai $\mathrm{r}_{\text {hitung }}$ dari masing-masing item pernyataan untuk setiap variabel diperoleh di atas 0,361 sehingga dapat dikatakan pernyataan yang digunakan dalam variabel penelitian dikatakan valid.

Tabel 2. Hasil Uji Reliabilitas

\begin{tabular}{llcc}
\hline No & \multicolumn{1}{c}{ Variabel } & Jumlah Item & $\begin{array}{c}\text { Cronbach's } \\
\text { Alpha }\end{array}$ \\
\hline 1 & Kualitas Pelayanan & 5 & 0,762 \\
\hline 2 & Promosi & 4 & 0,756 \\
\hline 3 & Kepuasan Pelanggan & 5 & 0,787 \\
\hline
\end{tabular}

Sumber : Hasil Olah Data, 2020

Dari tabel 2 juga diperoleh dari masing-masing variabel di Cronbach's Alpha tidak dibawah 0,6 sehingga dapat dinyatakan reliabel.

\section{Uji Asumsi Klasik}

Uji Normalitas

Uji normalitas bertujuan untuk menguji apakah dalam model regresi variabel pengganggu atau residual memiliki distribusi normal. Ada dua cara untuk mendeteksi apakah residual berdistribusi normal atau tidak, yaitu dengan analisis grafik dan uji statistik. 


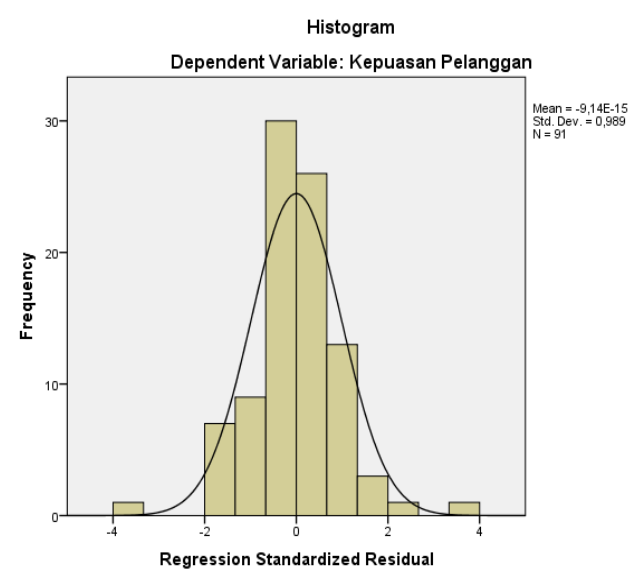

Gambar 2. Grafik Histogram

Dari Gambar 2 dapat dilihat bahwa data tegak lurus di atas angka 0, tidak melenceng ke kiri dan ke kanan, sehingga model regresi dianggap memenuhi asumsi normalitas.

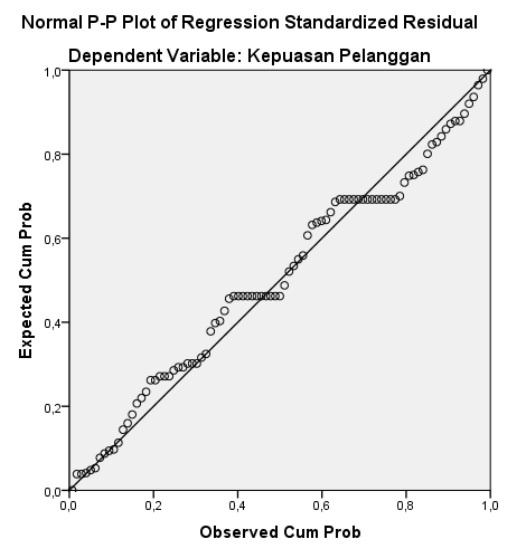

Gambar 3. Grafik Normal Probability Plot

Dari Gambar 3 menunjukkan bahwa data (titik) menyebar di sekitar garis normal dan mengikuti arah garis diagonal atau grafik Normal Probabilty Plot menunjukkan pola distribusi normal. 
Tabel 3. Uji One Kolmogrov-Smirnov

ne-Sample Kolmogorov-Smirnov Test

\begin{tabular}{llr} 
& & $\begin{array}{c}\text { Unstandardized } \\
\text { Residual }\end{array}$ \\
\hline $\mathrm{N}$ & Mean & 91 \\
Normal Parameters & a,b &, 0000000 \\
& Std. Deviation &, 20666350 \\
Most Extreme Differences & Absolute &, 089 \\
& Positive &, 089 \\
& Negative &,- 082 \\
Test Statistic & &, 089 \\
Asymp. Sig. (2-tailed) &, $073^{\mathrm{c}}$ \\
$\begin{array}{l}\text { a. Test distribution is Normal. } \\
\text { b. Calculated from data. } \\
\text { c. Lilliefors Significance Correction. }\end{array}$ \\
\hline
\end{tabular}

Sumber : Hasil Olah Data, 2020

Berdasarkan tabel 3 di atas, maka dapat diketahui nilai signifikan lebih besar dari 0,05 yaitu sebesar 0,073. Hasil pengujian ini menunjukkan bahwa data berdistribusi normal.

Uji Multikolinearitas

Tabel 4. Uji Multikolinearitas

\begin{tabular}{llcr}
\hline \multirow{2}{*}{$\begin{array}{l}\text { Model } \\
1\end{array}$} & \multicolumn{2}{c}{ Collinearity Statistics } \\
\cline { 2 - 4 } & Tolerance & \multicolumn{2}{c}{ VIF } \\
\cline { 2 - 4 } & Kualitas Pelayanan &, 716 & 1,397 \\
Promosi &, 716 & 1,397 \\
\hline
\end{tabular}

Sumber : Hasil Olah Data, 2020

Dari tabel 4 diketahui nilai Tolerance yang diperoleh dari variabel Kualitas Pelayanan dan variabel Promosi adalah 0,716 yang lebih dari 0,10 dan nilai VIF yang diperoleh adalah 1,397 yang kurang dari 10, sehingga dapat dinyatakan tidak terjadi persoalan multikolinearitas dengan variabel bebas lainnya. 
Uji Heteroskedastisitas

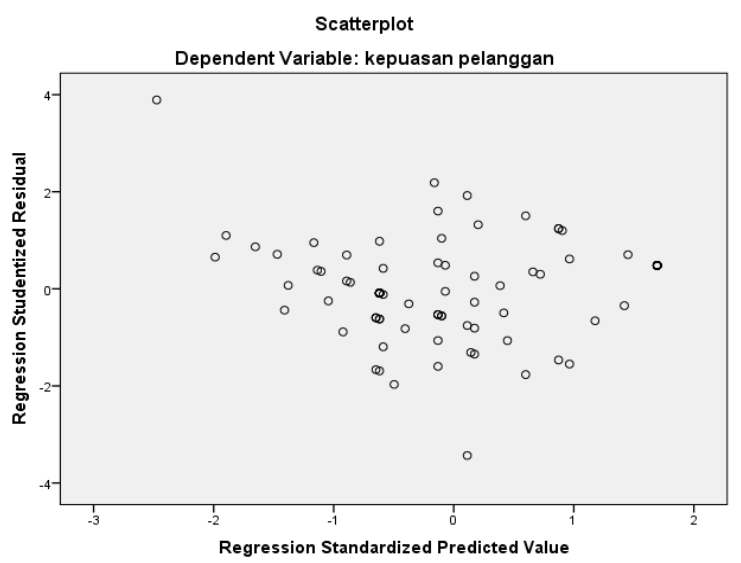

Sumber : Hasil Olah Data, 2020

Gambar 4. Uji Heteroskedastisitas

Berdasarkan Gambar 4 terlihat titik-titik secara acak atau tidak membentuk suatu pola tertentu yang jelas secara tersebar baik di atas maupun di bawah angka 0 pada sumbu Regression Studentized Residual (Y). Hal ini berarti tidak terjadi heteroskedasitas pada model regresi sehingga model regresi ini layak digunakan untuk memprediksi Kepuasan Pelanggan.

\section{Analisis Regresi Linear Berganda}

Tabel 5. Uji Analisis Regresi Linear Berganda

\begin{tabular}{|c|c|c|c|c|c|c|c|c|}
\hline \multicolumn{9}{|c|}{ Coefficients $^{\mathbf{a}}$} \\
\hline \multirow{2}{*}{\multicolumn{2}{|c|}{ Model }} & \multicolumn{2}{|c|}{$\begin{array}{c}\text { Unstandardized } \\
\text { Coefficients } \\
\text { Std. }\end{array}$} & \multirow{2}{*}{\multicolumn{2}{|c|}{$\begin{array}{l}\text { Standardized } \\
\text { Coefficients }\end{array}$}} & \multirow[b]{2}{*}{ Sig. } & \multicolumn{2}{|c|}{$\begin{array}{l}\text { Collinearity } \\
\text { Statistics }\end{array}$} \\
\hline & & & $\begin{array}{l}\text { Std. } \\
\text { Error }\end{array}$ & & & & Tolerance & VIF \\
\hline 1 & (Constant) & 4,389 & 2,008 & & 2,186 &, 031 & & \\
\hline & $\begin{array}{l}\text { Kualitas } \\
\text { Pelayanan }\end{array}$ & , 415 & ,103 & ,375 & 4,029 &, 000 &, 716 & 1,397 \\
\hline & Promosi & ,467 & , 110 & ,395 & 4,248 & ,000 & ,716 & 1,397 \\
\hline
\end{tabular}

Sumber : Hasil Olah Peneliti, 2020

Dari tabel 5, uji regresi linear berganda diperoleh persamaan regresinya adalah: Kepuasan Pelanggan = 4,389 + 0,415 Kualitas Pelayanan + 0,467 Promosi + e Penjelasan persamaan sebagai berikut :

1. 4,389 artinya jika Kepuasan Pelanggan yang diteliti konstan, maka Kepuasan Pelanggan OVO adalah sebesar 4,389.

2. 0,415 artinya jika setiap penambahan satu-satuan variabel Kualitas Pelayanan (X1) akan menyebabkan Kepuasan Pelanggan bertambah sebesar 0,415 satu-satuan dengan kondisi faktor variabel Promosi (X2) dianggap konstan.

3. 0,467 artinya jika setiap penambahan satu-satuan varibel Promosi (X2) akan 
menyebabkan Kepuasan Pelanggan bertambah sebesar 0,467 satu-satuan dengan kondisi faktor variabel Kualitas Pelayanan (X1) dianggap konstan.

\section{Pengujian Hipotesis}

\section{Uji t (Uji Secara Parsial)}

Uji t digunakan untuk melihat secara parsial apakah ada pengaruh yang signifikan dari variabel bebas terhadap variabel terikat. Bentuk pengujiannya adalah sebagai berikut:

1. $\mathrm{H}_{0}: \mathrm{b}_{1}, \mathrm{~b}_{2}=0$, Artinya Kualitas Pelayanan, Promosi secara parsial tidak berpengaruh terhadap Kepuasan Pelanggan OVO.

2. $\mathrm{H}_{\mathrm{a}}: \mathrm{b}_{1}, \mathrm{~b}_{2} \neq 0$, Artinya Kualitas Pelayanan, Promosi secara parsial berpengaruh terhadap Kepuasan Pelanggan OVO.

Tabel 6. Uji t (Uji Secara Parsial)

Coefficients $^{a}$

\begin{tabular}{|c|c|c|c|c|c|c|}
\hline \multirow{2}{*}{\multicolumn{2}{|c|}{ Model }} & \multicolumn{2}{|c|}{$\begin{array}{l}\text { Unstandardized } \\
\text { Coefficients }\end{array}$} & \multirow{2}{*}{$\begin{array}{c}\text { Standardized Coefficients } \\
\text { Beta }\end{array}$} & \multirow[t]{2}{*}{$\mathrm{t}$} & \multirow[t]{2}{*}{ Sig. } \\
\hline & & $\mathrm{B}$ & Std. Error & & & \\
\hline & (Constant) & 4,389 & 2,008 & & 2,186 &, 031 \\
\hline & Kualitas Pelayanan & ,415 & ,103 & ,375 & 4,029 &, 000 \\
\hline & Promosi & ,467 &, 110 & ,395 & 4,248 & ,000 \\
\hline
\end{tabular}

Dari tabel 6, diperoleh Nilai thitung untuk variabel Kualitas Pelayanan adalah 4,029 dengan tingkat signifikan 0,000. Dengan derajat bebas (df) sebesar $88(\mathrm{n}-\mathrm{k}=91$ responden -3$)$ dan taraf sig $\alpha=5 \%$ maka nilai $t_{\text {tabel }}$ adalah sebesar 1,987. Oleh karena nilai $t_{\text {hitung }}>t_{\text {tabel }}(4,029>$ 1,987) maka kriterianya adalah $\mathrm{H}_{0}$ ditolak, $\mathrm{H}_{\mathrm{a}}$ diterima sehingga Kualitas Pelayanan secara parsial berpengaruh positif dan signifikan terhadap Kepuasan Pelanggan OVO. Nilai thitung untuk variabel Promosi adalah 4,248 dengan tingkat signifikan 0,000. Dengan derajat bebas (df) sebesar $88(\mathrm{n}-\mathrm{k}=91$ responden -3$)$ dan taraf sig $\alpha=5 \%$ maka nilai tabel adalah sebesar 1,987. Oleh karena nilai thitung $>t_{\text {tabel }}(4,248>1,987)$ maka kriterianya adalah $\mathrm{H}_{0}$ ditolak, $\mathrm{H}_{\mathrm{a}}$ diterima sehingga Promosi secara parsial berpengaruh positif dan signifikan terhadap Kepuasan Pelanggan OVO.

\section{Uji F (Uji Secara Simultan)}

Uji F pada dasarnya menunjukan apakah semua variabel bebas yang dimasukkan dalam model mempunyai pengaruh secara simultan terhadap variabel dependen. Uji F digunakan untuk menguji pengaruh dimensi variabel bebas secara serempak terhadap variabel terikat. Bentuk pengujiannya adalah sebagai berikut:

1. $\mathrm{H}_{0}: \mathrm{b}_{1}, \mathrm{~b}_{2}=0$, Artinya Kualitas Pelayanan, Promosi secara serempak tidak berpengaruh terhadap Kepuasan Pelanggan OVO. 
2. $\mathrm{H}_{\mathrm{a}}: \mathrm{b}_{1}, \mathrm{~b}_{2} \neq 0$, Artinya Kualitas Pelayanan, Promosi secara serempak berpengaruh terhadap Kepuasan Pelanggan OVO.

Tabel 7. Uji F (Uji Secara Simultan)

\begin{tabular}{lrrrrr}
\hline Model & Sum of Squares & df & Mean Square & \multicolumn{1}{c}{ F } & Sig. \\
\hline $1 \quad$ Regression & 261,737 & 2 & 130,869 & 36,692 &, $000^{\mathrm{b}}$ \\
& 313,867 & 88 & 3,567 & & \\
$\quad$ Residual & 575,604 & 90 & & & \\
Total & & & & & \\
\hline
\end{tabular}

Sumber : Hasil Olah Data, 2020

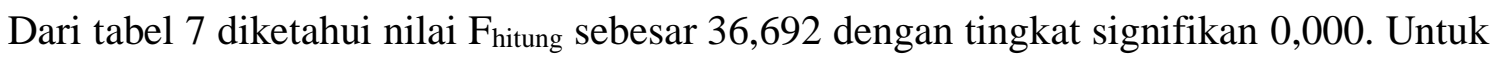
tingkat keyakinan $95 \%$ df $1=2$, dan df $2=88$ maka $F_{\text {tabel }}$ adalah 3,10. Oleh karena $F_{\text {hitung }}>F_{\text {tabel }}$ $(36,692>3,10)$, maka kriterianya adalah $\mathrm{H}_{0}$ ditolak, $\mathrm{H}_{\mathrm{a}}$ diterima sehingga dapat dinyatakan bahwa Kualitas Pelayanan dan Promosi secara serempak berpengaruh positif dan signifikan terhadap Kepuasan Pelanggan OVO.

Uji Koefisien Determinasi $\left(\mathrm{R}^{2}\right)$

Koefisien determinasi (R) pada intinya mengukur seberapa jauh kemampuan model dalam menerangkan variasi variabel dependen.

Tabel 8. Uji Koefisien Determinasi $\left(\mathrm{R}^{2}\right)$

\begin{tabular}{|c|c|c|c|c|}
\hline Model & $\mathrm{R}$ & R Square & Adjusted R Square & Std. Error of the Estimate \\
\hline 1 &, $674^{a}$ & 455 & ,442 & 1,889 \\
\hline
\end{tabular}

Dari tabel 8 diketahui bahwa koefisien determinasi $R$ Square yang digunakan untuk mengukur seberapa jauh kemampuan model dalam menerangkan variasi variabel dependen adalah 0,455. Hal ini menunjukkan bahwa 45,5\% Kepuasan Pelanggan OVO dipengaruhi oleh variabel Kualitas Pelayanan dan Promosi, sedangkan sisanya yaitu 54,5\% dipengaruhi oleh variabel-variabel seperti persepsi, digital marketing dan personal selling yang tidak diteliti dalam penelitian ini.

\section{KESIMPULAN DAN SARAN}

\subsection{Kesimpulan}

Berdasarkan hasil dan pembahasan penelitian, maka penulis membuat beberapa kesimpulan. Hasil penelitian ini menyatakan pengaruh Kualitas Pelayanan dan Promosi terhadap Kepuasan Pelanggan yang ditunjukkan dari hasil analisis regresi linear berganda memberikan arti bahwa setiap peningkatan aspek pada variabel Kualitas Pelayanan dan Promosi sebesar satu-satuan, maka Kepuasan Pelanggan akan meningkat.

Hasil Uji t menunjukkan bahwa Kualitas Pelayanan secara parsial memiliki pengaruh positif dan signifikan terhadap Kepuasan Pelanggan OVO. Hasil Uji t menunjukkan bahwa 
Promosi secara parsial memiliki pengaruh positif dan signifikan terhadap Kepuasan Pelanggan OVO. Hasil Uji F menunjukkan bahwa Kualitas Pelayanan dan Promosi secara serempak berpengaruh positif dan signifikan terhadap Kepuasan Pelanggan OVO. Hasil Uji koefisien determinasi (R2) menunjukkan bahwa variabel Kepuasan Pelanggan OVO dapat dijelaskan keterkaitannya oleh variabel Kualitas Pelayanan dan Promosi, sedangkan sisanya dipengaruhi oleh variabel-variabel lainnya yang tidak diteliti dalam penelitian ini seperti persepsi, digital marketing dan personal selling.

\subsection{Saran}

Berdasarkan analisa yang telah penulis lakukan, maka didapatkan saran yang dapat diberikan kepada OVO sebagai berikut :

1. Perusahaan harus mempertahankan Kualitas Pelayanan (X1) dalam meningkatkan Kepuasan Pelanggan (Y), seperti:

a. Mengirimkan konfirmasi via SMS atau media lainnya atas saldo yang telah di top-up oleh pelanggan sehingga pelanggan dapat memastikan top-up telah masuk menjadi saldo OVO.

b. Meminimalisir terjadinya error atau bug pada aplikasi OVO sehingga pengamanan (security) data pengguna dapat terlindungi.

2. Perusahaan harus memperhatikan Promosi (X2) dalam meningkatkan Kepuasan Pelanggan (Y), seperti:

a. Menyampaikan promosi tidak hanya dengan cara konvensional, salah satunya adalah dengan memasang iklan pada platform-platform terkenal seperti Youtube dan Instagram sehingga dapat menjangkau seluruh pengguna media sosial.

b. Menginformasikan kepada pelanggan melalui berbagai media sosial sehingga pelanggan akan selalu mengingat branding OVO sebagai salah satu penyedia layanan keuangan yang lengkap dengan promo-promo yang menarik.

\section{DAFTAR PUSTAKA}

Ghozali, I. (2016) Aplikasi Analisis Multivariete dengan Program IBM SPSS 23. 8th edn. Semarang: Universitas Diponegoro.

Hasan, A. (2013). Marketing dan Kasus - Kasus Pilihan. Yogyakarta: CAPS (Center For Academic Publishing Service).

Sunyoto, D. (2013). Teori, Kuesioner \& Analisis Data, Untuk Pemasaran dan Perilaku Konsumen. Yogyakarta: Graha Ilmu.

Sunyoto, D. (2014). Konsep Dasar Riset Pemasaran \& Perilaku Konsumen. Yogyakarta: CAPS (Center For Academic Publishing Service).

Tjiptono, F. (2017). Service Management. 3rd edn. Yogyakarta: CV. Andi Offset.

Tjiptono, F. dan Chandra, G. (2012). Pemasaran Strategik. Yogyakarta: CV. Andi Offset.

Tjiptono, F. dan Diana, A. (2019). Kepuasan Pelanggan - Konsep, Pengukuran, \& Strategi. Yogyakarta: CV. Andi Offset. 